\title{
An Empirical Analysis of Repurchase Behavior in Mobile Commerce According to Different Mobile Channels
}

\author{
Minhyung Lee \\ KAIST College of Business \\ winterlove@business.kaist.ac.kr
}

\author{
Junyeong Lee \\ USTC \\ junyeonglee@ustc.edu.cn
}

\author{
Chanhee Kwak \\ KAIST College of Business \\ kchhee@business.kaist.ac.kr
}

\author{
Sun-Young Yoon \\ KAIST College of Business \\ syyoon7@business.kaist.ac.kr
}

\author{
Heeseok Lee \\ KAIST College of Business \\ hsl@business.kaist.ac.kr
}

\begin{abstract}
Smartphone-based m-commerce enables customers to purchase products in different channels. In the complicated mobile shopping channels, retaining existing customers becomes important. In light of these developments, this study focuses on crucial factors of repurchase behavior of consumers based on the recency, frequency, and monetary value (RFM) model and analyzes how their effects differ among mobile channels and the online channel. The mobile channels are divided into three channels: mobile application ("app"), mobile browser, and mobile shopping portal channels. Real purchase data for three million orders from online shopping sites is used for our empirical analysis. The results show that all RFM variables significantly affect repurchase behavior. Our findings imply that mobile app users are more likely to repurchase than users in other channels. It is also found that the frequency variable is more important for mobile channel users, while the recency variable is more important for online channel users.
\end{abstract}

\section{Introduction}

The market size of mobile commerce (" $\mathrm{m}$ commerce" hereafter), an emerging subset of ecommerce [1], has increased drastically since the early 2010s when the penetration rate of smartphones increased at a rapid rate [2]. According to the U.S. Census Bureau and comScore, m-commerce accounted for $11.6 \%$ of the $\$ 303$ billion U.S. ecommerce total in 2014 [3]. The m-commerce market is forecasted to reach $\$ 284$ billion, which is $45 \%$ of the U.S. e-commerce total, by 2020 [3]. When mcommerce began, its growth seemed weaker than that of e-commerce owing to low usability of mobile phones, lack of technological infrastructure, switching costs, and perceived potential risks [4-7]. As a result, m-commerce was considered as a complementary shopping medium to e-commerce [8]. However, this view seemed to have changed after the introduction of smartphones in the market. Smartphones enable people to do almost everything they can do with personal computers (PCs). In addition, smartphone users enjoy direct Internet access through their devices, and this convenience accelerated the growth of $\mathrm{m}$ commerce [9].

The revival of m-commerce driven by smartphones have expanded the purchase channels for customers. With this increase in purchase channels, the retention of existing customers became more important for online and offline vendors to survive in the competitive market [10]. Besides, customer relationship management has been important to maintain consumer loyalty as buyers and sellers do not transact with each other directly in e-commerce and $\mathrm{m}$-commerce [11]. Accordingly, prior studies focused on the repurchase behavior of consumers in both offline and online commerce to measure consumer loyalty [12-16]. For example, one study concentrated on the influence of trust and media richness on repurchase intention [12] and the other study emphasized the impact of value-related and transaction cost-related factors on repurchase intention in the terms of online shoppers [13]. However, few studies stated how the different purchase channels influence the repurchase behavior of customers.

Especially, in m-commerce, its characteristics are different from existing e-commerce in terms of portability, information immediateness or locationspecificity [17]. These characteristics allow consumers to interact with brands easily on an anytime, anywhere basis [18]. In smartphone-based mcommerce, channels are various as well. Customers can access mobile shopping sites through mobile 
applications ("apps" hereafter), mobile browsers, or mobile shopping portal sites. However, few studies demonstrated the repurchase behavior in m-commerce, and they did not divide mobile channels into different types and describe them in detail, even though such types have different characteristics.

To fill this research gap, this study attempts to demonstrate repurchase behavior in m-commerce based on the recency, frequency, and monetary value (RFM) model according to different purchase channels. The RFM model consists of purchase behavior-related variables, namely recency, frequency, and monetary value. Since RFM model estimates customer value and purchase patterns and loyalty, it is suitable for the proxy of repurchase behavior [19, 20]. This study seeks to determine the effects of these variables on repurchase behavior according to different mobile channels and compare these effects with that of the online channel. A large dataset of real purchase data from 400 online clothing stores is used to examine the repurchase behavior of consumers empirically. The products that are most sold through the mobile service are clothing and technology products [21]. People also tend to give a positive response in different channels when they purchase clothing products through online stores [22]. In that sense, this study uses the online clothing sales data to investigate the different repurchase behavior of consumers according to different channels.

\section{Literature Review}

\subsection{Mobile Commerce}

M-commerce is an emerging subset of e-commerce [1], and defined as all financial transactions related to the purchase of products or services through a wireless network or mobile phones connected to an Internet network [23, 24]. The introduction of m-commerce has expanded the purchase channels in e-commerce. M-commerce provides many benefits to consumers, such as convenience, time savings, and enhanced overall quality of life [7]. Customers can search for products and pay with mobile devices whenever and wherever they are connected to a wireless Internet network $[25,26]$. As the penetration rate of smartphones has increased, the market size of $\mathrm{m}$ commerce has grown continuously [9]. Many mobile apps introduced with smartphones have contributed to the growth of the m-commerce market.

Previous researches on $\mathrm{m}$-commerce examined particular dimensions of m-commerce, such as mobile marketing, mobile advertising [27, 28] and mobile payments $[29,30]$. Some studies focused more on the adoption of m-commerce services. M-commerce adoption is usually associated with its convenience [30-32]. Wu and Wang [7] stated that perceived usefulness, perceived risks, costs, and compatibility affect m-commerce adoption. Meanwhile, other researchers identified the barriers to m-commerce adoption, namely privacy concerns, network security, transaction protection and trust [24, 33]. Perceived usefulness, perceived ease of use, and subjective norms also affect the adoption of m-commerce positively [24]. M-commerce users perceive potential risk as they receive insufficient information because of the constraints of mobile networks, terminals, and content [5].

In the early stages of m-commerce, it was indicated that low usability, lack of technological infrastructure, switching costs, and perceived potential risks influence the low adoption of m-commerce [4-7]. Other study demonstrated that $\mathrm{m}$-commerce is better when considered as a complementary shopping medium to e-commerce, rather than a direct alternative [8], because the usability of $\mathrm{m}$-commerce through mobile phones is far behind that of e-commerce through computer-based online network [4]. The screen size of previous mobile phones was too small to show all the information in a screen at once, so the usability of m-commerce was very low. Additionally, the speed of wireless network was very slow, compared to the speed of online networks, so users felt uncomfortable when they shopped through mobile phones. As a result, the growth of m-commerce was not noticeable.

However, technological advances, such as highspeed $3 \mathrm{G}$ mobile broadband and Internet-capable smartphones, have fostered the development of $\mathrm{m}$ commerce, with users enjoying direct Internet access through mobile devices [9]. As the screen size of smartphone enlarged and the speed of wireless Internet improved, the usability and convenience of mobile shopping improved and this enhancement accelerated the number of m-commerce users. Consequently, the emergence of smartphones accelerated the growth of $\mathrm{m}$-commerce and opened the second era of $\mathrm{m}$ commerce [9].

The characteristics of current era of m-commerce differ from those of e-commerce. M-commerce with smartphones can send push-alarms to customers based on their location and face less time and place constraints than e-commerce [17]. In light of these differences, there is a possibility that the shopping behavior of consumers in m-commerce in the era of smartphones is different from that of consumers in ecommerce. A few studies have investigated which factors have influence on the purchase intention in mobile commerce since the emergence of smartphones. 
Gao et al. [34] conducted survey-based research and found that information quality, and privacy and security concerns are the main factors for trust in $\mathrm{m}$ commerce, whereas service quality is the main factor affecting flow. Wolf et al. [35] found that the product price, the internet connection, and the mobile shop layout determine mobile shopping behavior. However, most of previous studies on m-commerce before and after the emergence of smartphones were based on the survey-method $[4,7,30,32,34,35]$. To determine the effects of purchase-related variables on real purchase behavior in m-commerce empirically, this study uses a real-world dataset collected from online and mobile clothing shopping stores.

\subsection{Repurchase}

A repurchase is related to customer relationship management. As the relationship between customers and companies becomes strong, customers tend to repurchase the products of those companies [36]. In ecommerce, where consumers do not transact with sellers directly, customer relationship management has played an important role to maximize the profit and growth of companies [11]. In the fast-changing business environment, customer retention is more efficient in achieving cost reduction and sales revenue increase [37]. Therefore, a better understanding of the repurchase behavior is important in maintaining existing consumers.

Previous studies focused more on purchase intention. As repurchase and purchase behaviors are subjective behaviors that are determined by consumer experience, it is important to see which factors affect consumers' repeat purchases in an online environment [13, 38]. Bolton [39] and Mittal and Kamakura [40] suggested that consumer satisfaction is related to repurchase behavior in the context of traditional commerce. They added that customer satisfaction is not the only factor that decides repurchase behavior, and that customer value, switching costs, and alternative value should be considered as well. Chen et al. [12] examined the effect of mediation strategies, trust, and media richness on the repurchase intention in online auction sites.

Many studies investigated the factors that affect repurchase intention in e-commerce $[12,13,41]$ and traditional commerce [39, 40], but few studies demonstrated repurchase intention in m-commerce. Furthermore, most studies used survey-based [13, 41] or experiment-based data [12] to analyze repurchase intention, but important unconscious behaviors that customers show when they actually make a repeat purchase of a product were ignored.

\subsection{Purchase Channel}

There are multiple purchasing channels in the shopping industry. Purchase channels are broadly categorized into two types: the offline channel and other channels. The offline channel refers to traditional purchase channels, such as offline stores or big retail stores. On the other hand, other channels include diverse non-offline channels, such as the catalog [42, 43], telephone [14], home-shopping [44], online [14, 42, 43, 45], and mobile channels [46, 47]. A number of studies focused on multi-channel shopping environments. Early studies compared the shopping behavior in online and offline channels. In the beginning of e-commerce, consumers tended to search for products in the online channel and purchase the products in the offline channel [48]. One study demonstrated the different movement across channels according to the characteristics of products. As the size of e-commerce market grew, more consumers moved from offline channel to online channel [49]. It is also found that trust in online brokerage service affects trust in mobile brokerage service positively [50]. Other literatures on multi-channel retailing concentrated on the purchase process and channel differences [44, 51]. However, the studies of the mobile channels in e-commerce are still rare.

Mobile purchase channels can be very effective owing to following five characteristics [17]: portability, personal relationships with owners, network and immediate information, visual and textual content, and convergence of services and functions. These characteristics allow consumers to interact with brands easily on an anytime, anywhere basis [18]. Unlike PC-based channels, mobile channels provide opportunities for brands to build relationships with customers and interact with them personally and frequently across space and time [47]. Therefore, the behavior of mobile channel users might differ from that of other channel users.

There is more than one type of mobile channels. Before the development of smartphones, m-commerce simply referred to the purchase of small products through a mobile browser. With smartphones, individuals can access mobile shopping sites through mobile apps, mobile browsers and mobile shopping portals. Mobile apps are developed by companies autonomously to optimize consumers' access to a mobile environment. Different from mobile browser channel, mobile apps can offer promotional deals and push alarms [23]. According to the consumer's specific location and time, immediate information can be provided to them. In light of these characteristics, mobile apps satisfy the criteria of mobile channels 
Table 1. Differences between Channels

\begin{tabular}{|c|c|c|c|c|}
\hline \multirow{2}{*}{ Channels } & \multicolumn{3}{|c|}{ Mobile } & Online \\
\cline { 2 - 5 } & App & Browser & Shopping Portal & No \\
\hline Location specificity & Yes & No & $\begin{array}{c}\text { Yes } \\
\text { (via push alarm) }\end{array}$ & $\begin{array}{c}\text { Yes } \\
\text { (via e-mail/banner ad) }\end{array}$ \\
\hline Customized offer & $\begin{array}{c}\text { Yes } \\
\text { (via push alarm) }\end{array}$ & No & $\begin{array}{c}\text { Yes } \\
\text { (via push alarm) }\end{array}$ & No \\
\hline $\begin{array}{c}\text { Immediate } \\
\text { information offer }\end{array}$ & $\begin{array}{c}\text { Yes } \\
\text { (via push alarm) }\end{array}$ & No & $\begin{array}{c}\text { Searching on } \\
\text { shopping portal } \\
\text { app }\end{array}$ & $\begin{array}{c}\text { Entering URL/searching } \\
\text { on portal website }\end{array}$ \\
\hline Access method & Clicking app & $\begin{array}{c}\text { Entering URL } \\
\text { address }\end{array}$
\end{tabular}

mentioned above. In addition, through mobile browsers, consumers can access mobile/online stores by entering their address on the browser. The characteristics of mobile browser channel are similar to those of online channel, except for portability. Mobile browsers, however, do not send customized offer or promotional deals as mobile apps, because they do not consider specific location of users. Last, the mobile shopping portal channel refers to a shopping portal site where many products from different stores are offered simultaneously (e.g., Amazon and Best Buy). A mobile shopping portal can provide push alarms to consumers at a specific time, but unlike mobile apps, the push alarms are provided by the shopping portal itself, not the individual shopping stores within the portal. From this perspective, the mobile channels can be divided into several types and described in detail. The differences between channels are detailed in Table 1 . Characteristics in Table 1 are determined and modified according to mobile channels' characteristics suggested by Shankar and Balasubramanian [17]. Customer behavior differs between mobile channel users and online or offline channel users, but it also differs in the different mobile channels. Customized services would increase customer trust and loyalty [52], and consequently, there is a possibility that mobile app users have more customer loyalty than other channel users.

In previous studies, purchase channels are mostly the traditional offline channel, Internet-based online channel, and telephone-based online channel [14, 4245]. A few studies focused on the mobile channel, but they were mostly before the emergence of smartphones [46, 47]. Since m-commerce experienced tremendous growth with smartphones, more research on m-commerce with smartphones is needed. In the competitive and complicated m-commerce market with the emergence of smartphones, differentiation of marketing strategy according to channel has become important. The primary objective of this study is to examine the repurchase behavior of consumers in $\mathrm{m}$ - commerce across the different mobile channels and the online channel. This study builds an empirical model based on the RFM model, which estimates customer value and behavior pattern. A large set of field data is used for our analysis in order to consider unconscious purchase behavior that is not measured by prior survey-based methods.

\section{Methods}

\subsection{Research Model}

To analyze purchase behavior related variables, the RFM model (recency, frequency and monetary value) is employed. Since RFM model was frequently used to estimate customer value, purchase patterns, and loyalty $[19,20]$, it is considered as appropriate for analyzing repurchase behavior. Recency refers to how recently customers last purchased a product, and this variable can be represented by the latest purchase date. The more recently a customer last purchased, the more likely he/she is to repurchase. Meanwhile, frequency indicates how often the customers purchase, and this variable can be denoted by the number of purchases during a specific purchase period. The more frequently a customer purchases, the stronger the loyalty is. Finally, monetary value means how much customers spend, and this variable is represented by the sum of the purchase values during a specific period. Consumers tend to make a repeat purchase from the same brand when the purchase amount of the previous purchase is large. In sum, more recent and more frequent purchases are expected to result in repurchases, and a larger purchase amount is more likely to result in a repurchase.

To analyze how differently RFM variables affect repurchase among different channels, this study considers channel variables as moderators. In this study, channels include mobile and online channels, and the mobile channel is further divided into the mobile app, mobile browser, and mobile shopping portal channels. 


\subsection{Field Data}

This study uses 6-months real-world sales data of 400 online clothing shopping site. The most popular categories for mobile shopping are clothing and technology products [21, 53] and consumers also response positively in different sales channels when they purchase clothing products in online stores [22]. People tend to repeat purchasing clothing product, because of their continued appetite for footwear or accessories. The conversion rate for mobile devices in clothing categories has also increased after the introduction of tablet PCs. Therefore, this study uses online clothing sales data to analyze the different repurchase behaviors of consumers in different mobile and online channels.

The dataset is collected from 400 online clothing shopping sites from November 2016 to April 2017. The dataset includes log data of customers' purchase and the information on their access channel and device. After excluding several inappropriate datasets, such as cancelled and repeated orders, our final dataset includes the purchase data of 2,943,710 orders. There are 191,121 customers when grouped by order ID. Among 191,121 consumers, only 42,450 customers are noted to repurchase in the same shopping sites.

\subsection{Analysis}

The dependent variable in our research model is repurchase behavior, which is denoted as 1 if a customer, who purchased in the preceding month, purchases again in the repurchase month, and is otherwise 0 . The purchase period is set by considering the characteristics of products in our data. The products in our dataset are mostly clothes from online fashion shopping malls. Clothes from online fashion shops like H\&M, ZARA, and GAP are usually considered as fast fashion. Fast fashion shops usually display products for three to five weeks and offer clothes with new or innovative designs [54]. Since consumers tend to purchase fast fashion clothes in a short cycle, we set the duration of the purchase period as one month.

Purchase- and channel-related variables are included as explanatory variables. Purchase-related variables are based on the RFM model. Recency denotes the difference between the latest purchase date and the start date of the repurchase month. Frequency includes two variables, namely the number of purchases in the month before the repurchase month and the purchase cycle during the purchase month. The cycle is defined as the difference between the first and the last purchase dates during the purchase period divided by the total number of purchases during a onemonth cycle. The calculation of the cycle is employed from Lee et al. [16]. Finally, monetary value includes both the total purchase value and average value per purchase item during one-month cycle. Considering the possible correlation between the total number and total value of purchases, we conduct a correlation analysis and find no significant correlation between the average value per purchase item and total value of purchases. To see the different effects according to channel, channel-related variables are included. The channels are divided into four types - the mobile app, mobile browser, mobile portal, and online PC channels - each of which is included as a dummy variable in the model.

Our base model is used to observe the effect of channels on repurchase behavior. Then, an additional model with the interaction effect of channel variables and purchase behavior variables is used to identify whether the effect of purchase behavior varies depending on channels.

\section{Analysis Results}

\subsection{Descriptive Statistics}

We analyze the dataset descriptively before the empirical analysis. In the model, the monetary variables are presented in the natural logarithmic form because of their skewness and extremely large value compared to the other variables. To check for possible multi-collinearity among the variables, correlation analysis is carried out. The correlation analysis results indicate no noticeable correlation between variables. VIF test is conducted, and the results show that VIF of all variables are lower than 3, having 2.07 as the biggest VIF. Consequently, there is no multicollinearity between explanatory variables. Among 191,215 consumers, the number of mobile app, mobile

Table 2. Descriptive Statistics

\begin{tabular}{|c|c|c|c|c|}
\hline Variables & Mean & SD & Min & Max \\
\hline Repurchase & 0.222 & 0.416 & 0 & 1 \\
\hline Recency & 11.181 & 7.540 & 0 & 29 \\
\hline $\begin{array}{c}\text { Num } \\
\text { Purchase }\end{array}$ & 2.706 & 3.362 & 1 & 646 \\
\hline Cycle & 6.254 & 5.821 & 0 & 29 \\
\hline TotalValue & 201,353 & $4,953,064$ & 1,000 & $2.15 \mathrm{E}+09$ \\
\hline $\begin{array}{c}\text { Average } \\
\text { ItemValue }\end{array}$ & 32,405 & 50,314 & 1.012 & $1.64 \mathrm{E}+07$ \\
\hline MobileApp & 0.327 & 0.469 & 0 & 1 \\
\hline $\begin{array}{c}\text { Mobile } \\
\text { Browser }\end{array}$ & 0.316 & 0.465 & 0 & 1 \\
\hline $\begin{array}{c}\text { Mobile } \\
\text { Portal }\end{array}$ & 0.158 & 0.365 & 0 & 1 \\
\hline OnlinePC & 0.199 & 0.399 & 0 & 1 \\
\hline
\end{tabular}


Table 3. Correlation Matrix

\begin{tabular}{|c|c|c|c|c|c|c|c|c|c|}
\hline & $(1)$ & $(2)$ & $(3)$ & $(4)$ & $(5)$ & $(6)$ & $(7)$ & $(8)$ & $(9)$ \\
\hline$(1)$ & $\mathbf{1 . 0 0}$ & & & & & & & & \\
\hline$(2)$ & $\mathbf{- 0 . 0 7}$ & $\mathbf{1 . 0 0}$ & & & & & & & \\
\hline$(3)$ & $\mathbf{- 0 . 4 0}$ & $\mathbf{- 0 . 1 1}$ & $\mathbf{1 . 0 0}$ & & & & & & \\
\hline$(4)$ & $\mathbf{- 0 . 0 1}$ & $\mathbf{0 . 0 8}$ & $\mathbf{- 0 . 0 1}$ & $\mathbf{1 . 0 0}$ & & & & & \\
\hline$(5)$ & $\mathbf{0 . 0 1}$ & $\mathbf{0 . 0 3}$ & $\mathbf{- 0 . 0 4}$ & $\mathbf{0 . 0 4}$ & $\mathbf{1 . 0 0}$ & & & & \\
\hline$(6)$ & $\mathbf{- 0 . 0 4}$ & $\mathbf{- 0 . 0 2}$ & $\mathbf{0 . 0 6}$ & $\mathbf{- 0 . 0 1}$ & $\mathbf{- 0 . 0 6}$ & $\mathbf{1 . 0 0}$ & & & \\
\hline$(7)$ & $\mathbf{0 . 0 3}$ & 0.00 & $\mathbf{- 0 . 0 6}$ & -0.00 & $\mathbf{0 . 0 0}$ & $\mathbf{- 0 . 4 7}$ & $\mathbf{1 . 0 0}$ & & \\
\hline$(8)$ & $\mathbf{0 . 0 1}$ & $\mathbf{- 0 . 0 2}$ & $\mathbf{- 0 . 0 1}$ & 0.00 & $\mathbf{0 . 0 4}$ & $\mathbf{- 0 . 3 5}$ & $\mathbf{- 0 . 3 4}$ & $\mathbf{1 . 0 0}$ & \\
\hline$(9)$ & -0.00 & $\mathbf{0 . 0 3}$ & $\mathbf{0 . 0 2}$ & $\mathbf{0 . 0 1}$ & $\mathbf{0 . 0 4}$ & $\mathbf{- 0 . 3 0}$ & $\mathbf{- 0 . 2 9}$ & $\mathbf{- 0 . 2 2}$ & $\mathbf{1 . 0 0}$ \\
\hline
\end{tabular}

Note: Bold values indicate correlations, which are significant at $\mathrm{p}<0.05$.

(1) Recency, (2) NumPurchase, (3) Cycle, (4) TotalValue, (5) AverageItemValue, (6) MobileApp, (7) MobileBrowser, (8)

MobilePortal, and (9) OnlinePC

browser, mobile shopping portal, and online channel users are 62,526, 60,337, 38,062, and 38,062, respectively. The detailed descriptive statistics are presented in Table 2, and the correlation matrix is shown in Table 3.

\subsection{Logistic Regression}

This study conducts a logistic regression to test the research model. The dependent variable, the repurchase decision, has a binary value-whether customers repurchased or not. In this case, a logistic regression analysis is the most appropriate analysis method. For the channel variables, the online PC channel is set as the base model, as (n-1) dummy variables are included when the categorical variable has $n$ values. Therefore, the variable of the online PC channel is not included in the logistic regression equation. The logistic regression equation of the base model (model 1) is described below.

$\operatorname{Logit}_{\left(\text {Repurchase }_{i}\right)=}$

$\beta_{0}+\beta_{1} *$ Recency $_{i}+\beta_{2} *$ NumPurchase $i+\beta_{3} *$ Cycle $_{i}$

$+\beta_{4} * \ln (\text { TotalValue })_{i}+\beta_{5} * \ln (\text { AverageItemValue })_{i}$

$+\beta_{6} *$ MobileAPP $_{i}+\beta_{7} *$ MobileBrowser $_{i}$

$+\beta_{8} *$ MobilePortal $_{i}+\varepsilon_{i}$

The additional model (model 2) for interaction effect is below. Mobile channels have different characteristics from each other, so there is a possibility that the effects of purchase-related variables differ among the mobile and online channels. To determine the moderating effects of purchase channels, the interaction term between purchase-behavior-related and channel variables is included.
$\operatorname{Logit}_{\left(\text {Repurchase }_{i}\right)}=$

$\beta_{0}+\beta_{1} *$ Recency $_{i}+\beta_{2} *$ NumPurchase $_{i}+\beta_{3} *$ Cycle $_{i}$ $+\beta_{4} * \ln (\text { TotalValue })_{i}+\beta_{5} * \ln \left(\right.$ AverageItemValue $_{i}$

$+\beta_{6} *$ MobileAPP $_{i}+\beta_{7} *$ MobileBrowser $_{i}$

$+\beta_{8} *$ MobilePortal $_{i}$

+ MobileAPP

$*\left(\begin{array}{c}\beta_{9} * \text { Recency }_{i}+\beta_{10} * \text { NumPurchase }_{i}+\beta_{11} * \text { Cycle }_{i} \\ +\beta_{12} * \ln \left(\text { TotalValue }_{i}+\beta_{13} * \ln \left(\text { AverageItemValue }_{i}\right.\right.\end{array}\right)$

+ MobileBrowser $_{i}$

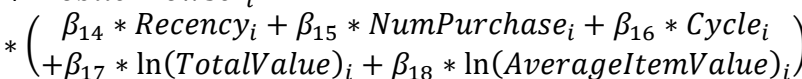

+ MobilePortal $_{i}$

$*\left(\begin{array}{c}\beta_{19} * \text { Recency }_{i}+\beta_{20} * \text { NumPurchase }_{i}+\beta_{21} * \text { Cycle }_{i} \\ +\beta_{22} * \ln \left(\text { TotalValue }_{i}+\beta_{23} * \ln \left(\text { AverageItemValue }_{i}\right.\right.\end{array}\right)$

$+\varepsilon_{i}$

\subsection{Analysis Results}

Our analysis result for the base model (model 1) is presented in Table 4 . All the variables are statistically significant. The recency variable shows a negative coefficient, which means that consumers who purchased recently are more likely to purchase again the following month. Both frequency variables show positive coefficients, which means that the higher the number of purchases, the more a customer is likely to repurchase. When the purchase cycle is long, repurchase probability increases. The monetary variables show different directions for their coefficients. Customers tend to repurchase when the total value of previous purchases is large and the average value per purchase item is small. Customers who purchase cheap products with more frequency are more likely to repurchase than consumers who make one-time purchases of expensive products.

All the channel dummy variables have positive coefficients, which means that customers tend to repurchase more in all mobile channels than in the online channel. Based on the size of the coefficient of each channel variable, mobile app users are most likely to repurchase. The repurchase rate of consumers is high in the mobile app channel, followed by the 
mobile browser channel, mobile portal channel and online channel.

\subsection{Moderating Effect}

The results of additional model (model 2) in Table 4 depict the moderating effect of purchase channels. The coefficients of purchase-behavior-related variables are consistent with the results of the analysis using the base model. The interaction terms between the purchase-behavior-related and channel variables differ for each channel.
For mobile apps, the effect of the recency variable decreases, while the effects of the frequency variables increase. Among the monetary value variables, the impact of average value per purchase item increases, but that of total value decreases. The results for mobile browsers and mobile shopping portals are similar to those for mobile apps, except for the results for the monetary variables. For the mobile browser channel, there is no significant moderating effect on total value of purchases in the month preceding the repurchase month. For the mobile shopping portal channel, the average value per purchase items is not significantly moderated by the channel variable.

Table 4. Hierarchical Logistic Regression Results

\begin{tabular}{|c|c|c|c|c|c|}
\hline \multirow{2}{*}{ Model } & \multirow{2}{*}{$\frac{\text { DV: logit(Repurchase) }}{\text { Variables }}$} & \multicolumn{2}{|c|}{ Model 1} & \multicolumn{2}{|c|}{ Model 2} \\
\hline & & Coefficients & Z-statistics & Coefficients & Z-statistics \\
\hline \multirow{8}{*}{$\begin{array}{l}\text { Independent } \\
\text { Variables }\end{array}$} & Recency & $-0.0355^{* * *}$ & $(-40.76)$ & $-0.0583 * * *$ & $(-24.13)$ \\
\hline & NumPurchase & $0.0567 * * *$ & $(13.92)$ & $0.0126 * * *$ & $(3.25)$ \\
\hline & Cycle & $0.0234 * * *$ & $(22.43)$ & $0.0091 * * *$ & $(3.29)$ \\
\hline & $\ln ($ TotalValue $)$ & $0.3845 * * *$ & $(39.86)$ & $0.4790 * * *$ & $(22.65)$ \\
\hline & $\ln$ (AverageItemValue) & $-0.2029 * * *$ & $(-21.05)$ & $-0.1593 * * *$ & $(-8.77)$ \\
\hline & MobileApp & $0.4943 * * *$ & $(27.81)$ & $3.3667 * * *$ & $(10.02)$ \\
\hline & MobileBrowser & $0.2056 * * *$ & $(11.19)$ & $1.0583 * * *$ & $(3.23)$ \\
\hline & MobilePortal & $0.1615 * * *$ & $(8.05)$ & $1.2351 * * *$ & $(3.42)$ \\
\hline \multirow{15}{*}{$\begin{array}{l}\text { Moderating } \\
\text { Variables }\end{array}$} & Recency*MobileApp & - & - & $0.0296 * * *$ & $(10.53)$ \\
\hline & NumPurchase*MobileApp & - & - & $0.1210 * * *$ & $(11.83)$ \\
\hline & Cycle ${ }^{*}$ MobileApp & - & - & $0.0131 * * *$ & $(4.03)$ \\
\hline & In(TotalValue)*MobileApp & - & - & $-0.2125 * * *$ & $(-7.78)$ \\
\hline & $\begin{array}{l}\text { ln(AverageItemValue }) \\
* \text { MobileApp }\end{array}$ & - & - & $-0.1038 * * *$ & $(-3.79)$ \\
\hline & Recency*MobileBrowser & - & - & $0.0249 * * *$ & $(8.65)$ \\
\hline & NumPurchase ${ }^{*}$ MobileBrowser & - & - & $0.0256 * *$ & $(3.02)$ \\
\hline & Cycle*MobileBrowser & - & - & $0.0237 * * *$ & $(7.05)$ \\
\hline & $\ln ($ TotalValue $) *$ MobileBrowser & - & - & -0.0509 & $(-1.85)$ \\
\hline & $\begin{array}{l}\text { In(AverageItemValue }) \\
\text { *MobileBrowser }\end{array}$ & - & - & $-0.0694 * *$ & $(-2.71)$ \\
\hline & Recency*MobilePortal & - & - & $0.0272 * * *$ & $(8.62)$ \\
\hline & NumPurchase ${ }^{*}$ MobilePortal & - & - & $0.1583 * * *$ & $(11.9)$ \\
\hline & Cycle*MobilePortal & - & - & $0.0241 * * *$ & $(6.49)$ \\
\hline & $\ln (\text { TotalValue })^{*}$ MobilePortal & - & - & $-0.1676 * * *$ & $(-5.34)$ \\
\hline & $\begin{array}{l}\text { In(AverageItemValue }) \\
\text { *MobilePortal }\end{array}$ & - & - & 0.0056 & $(0.20)$ \\
\hline \multicolumn{2}{|l|}{ Constant } & $-3.9426 * * *$ & $(-33.58)$ & $-5.0771 * * *$ & $(-20.25)$ \\
\hline \multicolumn{2}{|c|}{ Number of Observations } & \multicolumn{2}{|c|}{191,121} & \multicolumn{2}{|c|}{191,121} \\
\hline \multicolumn{2}{|l|}{ Pseudo $\mathrm{R}^{2}$} & \multicolumn{2}{|c|}{0.0418} & \multicolumn{2}{|c|}{0.0440} \\
\hline
\end{tabular}




\section{Conclusion}

This study examines the effect of the RFM variables on repurchase behavior in $\mathrm{m}$-commerce according to purchase channel. In our analyses, the mobile channel is divided into three types, namely the mobile app, mobile browser, and mobile shopping portal channels. Our major finding is that consumers are more likely to repurchase when they have access through mobile apps. The repurchase likelihood of consumers is high in the mobile app channel, followed by mobile browser, mobile portal, and online channels. The more recently and frequently they purchased in the purchase month, the more consumers tend to repurchase in the following month. Consumers are also likely to repurchase when the purchase cycle is long, the total purchase value is high, and the average purchase value per item is low. For mobile app users, recency and purchase cycle affects repurchase behavior less than other channel users. The average value per item influences mobile app users more. For online channel users, recency has the highest influence and frequency has the lowest.

\subsection{Theoretical Implications}

Our findings contribute to the literature on repurchase behavior with big data analysis. Most prior studies based on the survey-method have limitations since they do not consider unconscious actual purchase behavior. Our field data analyses benefit from the consideration of unobserved real purchase behavior, and consequently, fill the research gap in the literature. Our approach is consistent with the emerging theme of big data that emphasizes the importance of field data with statistical analysis.

This study also contributes to the expansion of the literature on $\mathrm{m}$-commerce by examining the effects of different purchase channels. The mobile channel has been considered a complementary channel to the online channel in previous studies because of the limited usability of mobile phones and lack of technical infrastructure. As the m-commerce market grows after the diffusion of smartphones, our initial analyses of m-commerce via various channels are of importance for future research.

\subsection{Managerial Implications}

Our most important managerial implication is that customers with mobile apps are more likely to repurchase than other channel users. Managers need to encourage customers to use mobile apps, so that they can revisit the online store and place more orders. Some companies are already doing promotional events to encourage consumers to install and use their mobile apps, and this phenomenon exemplifies how the mobile app channel is important for maintaining consumers.

Second, our interaction analysis implies that managers should pay more attention to the frequency of previous purchases than recency of purchases in most mobile channels, as the analysis results indicate that the frequency variable affects repurchase behavior more than the recency variable for mobile channel users. Thus, it is more important to prompt consumers to purchase more often than to prompt recent consumers to purchase again. These findings are useful for marketing strategies in m-commerce.

\subsection{Future Research Opportunities}

Like other studies, our study has limitations. First, our dataset only includes fast fashion products from online fashion stores. Even though clothing is the product that is sold most through mobile commerce, the consumption pattern and choice of purchase channels vary depending on the characteristics of products [49]. Thus, analyses with data for other types of products seem necessary to generalize results. Second, consumer demographic information is missing in our dataset because of the privacy issue. Since repurchase behavior might differ according to age, gender, and previous shopping experiences, future studies with demographic information will capture the unobserved effect of consumer characteristics. Lastly, multi-channel users are not considered in our dataset since the number of multichannel users is too small. A comparison between multi-channel and single channel users show interesting results for e-commerce $[45,55]$, and thus, the analysis in case of m-commerce between multichannel and single channel users is of interest.

\section{References}

[1] Siau, K., and Shen, Z., "Building Customer Trust in Mobile Commerce", Communications of the ACM, 46(4), 2003, pp. 9194.

[2] "Smartphone Penetration Rate as Share of the Population in the United States from 2010 to 2021", Statista, retrieved from https://www.statista.com/statistics/201183/forecast-ofsmartphone-penetration-in-the-us/, accessed June 6, 2017.

[3] "The Rise of M-Commerce: Mobile Shopping Stats \& Trends", Meola, A., Business Insider, retrieved from http://www.businessinsider.com/mobile-commerce-shoppingtrends-stats-2016-10, accessed June 8, 2017. 
[4] Venkatesh, V., Ramesh, V., and Massey, A.P., "Understanding Usability in Mobile Commerce", Communications of the ACM, 46(12), 2003, pp. 53-56.

[5] Wu, J.-H., and Hisa, T.-L., "Analysis of E-Commerce Innovation and Impact: A Hypercube Model", Electronic Commerce Research and Applications, 3(4), 2005, pp. 389-404.

[6] Chen, P.-Y., and Hitt, L.M., "Measuring Switching Costs and the Determinants of Customer Retention in InternetEnabled Businesses: A Study of the Online Brokerage Industry", Information Systems Research, 13(3), 2002, pp. 255-274.

[7] Wu, J.-H., and Wang, S.-C., "What Drives Mobile Commerce?: An Empirical Evaluation of the Revised Technology Acceptance Model", Information \& Management, 42(5), 2005, pp. 719-729.

[8] Ozok, A.A., and Wei, J., "An Empirical Comparison of Consumer Usability Preferences in Online Shopping Using Stationary and Mobile Devices: Results from a College Student Population", Electronic Commerce Research, 10(2), 2010, pp. 111-137.

[9] Giaglis, G.M., and Kourouthanassis, P.E., "Introduction to the Special Issue Mobile Commerce: The Past, Present, and Future of Mobile Commerce Research", International Journal of Electronic Commerce, 16(4), 2012, pp. 5-18.

[10] Johnson, C., Hult, P., and Mcgowan, B., "Web Buyers and Their Expectations Grow Up: Experienced Web Buyers Are Becoming the New Mainstream", Forrester, 2008.

[11] Chen, Y.-C., Shang, R.-A., and Kao, C.-Y., "The Effects of Information Overload on Consumers' Subjective State Towards Buying Decision in the Internet Shopping Environment", Electronic Commerce Research and Applications, 8, 2009, pp. 48-58.

[12] Chen, J.V., Yen, D.C., Kuo, W.-R., and Capistrano, E.P.S., "The Antecedents of Purchase and Repurchase Intentions of Online Auction Consumers", Computers in Human Behavior, 54, 2016, pp. 186-196.

[13] Wu, L.-Y., Chen, K.-Y., Chen, P.-Y., and Cheng, S.-L., "Perceived Value, Transaction Cost, and Repurchase-Intention in Online Shopping: A Relational Exchange Perspective", Journal of Business Research, 67(1), 2014, pp. 2768-2776.

[14] Magnini, V.P., and Karande, K., "Understanding Consumer Services Buyers Based Upon Theri Purchase Channel", Journal of Business Research, 64(6), 2011, pp. 543-550.

[15] Geyskens, I., Gielens, K., and Dekimpem, M.G., "The Market Valuation of Internet Channel Additions", Journal of Marketing, 66(2), 2002, pp. 102-119.

[16] Lee, J., Lee, J., Lee, H., and Lee, J., "An Explanatory Study of Factors Influencing Repurchase Behaviors toward Game Items: A Field Study", Computers in Human Behavior, 53, 2015, pp. 13-23.
[17] Shankar, V., and Balasubramanian, S., "Mobile Marketing: A Synthesis and Prognosis", Journal of Interactive Marketing, 23(2), 2009, pp. 118-129.

[18] Shankar, V., Venkatesh, A., Hofacker, C., and Naik, P., "Mobile Marketing in the Retailing Environment: Current Insights and Future Research Avenues", Journal of Interactive Marketing, 24(2), 2010, pp. 111-120.

[19] Bult, J.R., and Wansbeek, T., "Optimal Selection for Direct Mail", Marketing Science, 14(4), 1995, pp. 378-394.

[20] Fader, P.S., Hardie, B.G., and Lee, K.L., "Rfm and Clv: Using Iso-Value Curves for Customer Base Analysis", Journal of Marketing Research, 42(4), 2005, pp. 415-430.

[21] Pantano, E., And Priporas, C., "The Effect of Mobile Retailing on Consumers' Purchasing Experiences: A Dynamic Perspective", Computers in Human Behavior, 61, 2016, pp. 548555.

[22] Heinonen, K., And Strandvik, T., "Consumer Responsiveness to Mobile Marketing", International Journal of Mobile Communications, 5(6), 2007, pp. 603-617

[23] Kang, J.-Y.M., Mun, J.M., and Johson, K.K., "In-Store Mobile Usage: Downloading and Usage Intention toward Mobile Location-Based Retail Apps", Computers in Human Behavior, 46, 2015, pp. 210-217.

[24] Wong, C.H., Lee, H., Lim, Y.H., Chua, B.H., and Tan, G., "Predicting the Consumers' Intention to Adopt Mobile Shopping: An Emerging Market Perspective", International Journal of Network and Mobile Technologies, 3(3), 2012, pp. 24-39.

[25] Lu, H.-P., and Su, P.Y.-J., "Factors Affecting Purchase Intention on Mobile Shopping Web Sites", Internet Research, 19(4), 2009, pp. 442-458.

[26] Yang, K., and Kim, H.-Y., "Mobile Shopping Motivation: An Application of Multiple Discriminant Analysis", International Journal of Retail \& Distribution Management, 40(10), 2012, pp. 778-789.

[27] Park, T., Shenoy, R., and Salveny, G., "Effective Advertising on Mobile Phones: A Literature Review and Presentation of Results from 53 Case Studies", Behaviour \& Information Tehcnology, 27(5), 2008, pp. 355-373.

[28] Varnali, K., and Toker, A., "Mobile Marketing Research: The-State-of-the-Art", International Journal of Information Management, 30(2), 2010, pp. 144-151.

[29] Dahlberg, T., Mallat, N., Ondrus, J., and Zmijewska, A., "Past, Present and Future of Mobile Payments Research: A Literature Review", Electronic Commerce Research and Applications, 7(2), 2008, pp. 165-181.

[30] Kim, C., Mirusmonov, M., and Lee, I., "An Empirical Examination of Factors Influencing the Intention to Use Mobile 
Payment", Computers in Human Behavior, 26(3), 2010, pp. 310-322.

[31] Chae, M., and Kim, J., "What's So Different About the Mobile Internet?", Communications of the ACM, 46(12), 2003, pp. 240-247.

[32] Luarn, P., and Lin, H.-H., "Towards an Understanding of the Behavioral Intention to Use Mobile Banking", Computers in Human Behavior, 21(6), 2005, pp. 873-891.

[33] Kim, G., Shin, B., and Lee, H., "Understanding Dynamics between Initial Trust and Usage Intentions of Mobile Banking", Information Systems Research, 19(3), 2009, pp. 283-311.

[34] Gao, L., Waechter, K.A., and Bai, X., "Understanding Consumers' Continuance Intention Towards Mobile Purchase: A Theoretical Framework and Empirical Study - a Case of China", Computers in Human Behavior, 53, 2015, pp. 249-262.

[35] Wolf, L., Bick, M., and Kummer, T.-F., "The Influence of Situation-Dependent Factors on Mobile Shopping Usage", Proceedings of the 50th Hawaii International Conference on System Sciences, 2017.

[36] Fornell, C., "A National Customer Satisfaction Barometer: The Swedish Experience", Journal of Marketing, 56(1), 1992, pp. 6-21.

[37] Anderson, E.W., and Sullivan, M.W., "The Antecedents and Consequences of Customer Satisfaction for Firms", Marketing Science, 12(2), 1993, pp. 125-143.

[38] Chen, Y.-Y., "Why Do Consumers Go Internet Shopping Again? Understanding the Antecedents of Repurchase Intention", Journal of Organizational Computing and Electronic Commerce, 22(1), 2012, pp. 1532-7744.

[39] Bolton, R.N., "A Dynamic Model of the Duration of the Customer's Relationship with a Continuous Service Provider: The Role of Satisfaction", Marketing Science, 17(1), 1998, pp. 45-65.

[40] Mittal, V., and Kamakura, W.A., "Satisfaction, Repurchase Intent and Repurchase Behavior: Investigating the Moderating Effect of Customer Characteristics", Journal of Marketing Research, 38(1), 2001, pp. 131-142.

[41] Chiu, C.-M., Wang, E.T.G., Fang, Y.-H., and Huang, H.Y., "Understanding Customers' Repeat Purchase Intentions in B2c E-Commerce: The Roles of Utilitarian Value, Hedonic Value and Perceived Risk", Information Systems Journal, 24, 2014, pp. 85-114.

[42] Schoenbachler, D.D., and Gordon, G.L., "Multi-Channel Shopping: Understanding What Drives Channel Choice", Journal of Consumer Marketing, 19(1), 2002, pp. 42-53.

[43] Konus, U., Verhoef, P.C., and Neslin, S.A., "Multichannel Shopper Segments and Their Covariates", Journal of Retailing, 84, 2008, pp. 398-413.
[44] Alba, J., Lynch, J., Weitz, B., Janiszewski, C., Lutz, R., Sawyer, A., and Wood, S., "Interactive Home Shopping: Consumer, Retailer, and Manufacturer Incentives to Participate in Electronic Marketplaces", Journal of Marketing, 61(3), 1997, pp. $38-53$.

[45] Baal, S.V., and Dach, C., "Free Riding and Customer Retention across Retailers' Channels", Journal of Interactive Marketing, 19(2), 2005, pp. 75-85.

[46] Bigne, E., Ruiz, C., and Silvia, S., "The Impact of Internet User Shopping Patterns and Demographics on Consumer Mobile Buying Behavior", Journal of Electronic Commerce Research, 6(3), 2005, pp. 193-209.

[47] Wang, R.J.-H., Malthouse, E.C., and Krishnamurthi, L., "On the Go: How Mobile Shopping Affects Customer Purchase Behavior", Journal of Retailing, 91(2), 2015, pp. 217-234.

[48] Kaufman-Scarborough, C., and Lindquist, J.D., "EShopping in a Multiple Channel Environment", Journal of Consumer Marketing, 19(4), 2002, pp. 333-350.

[49] Cheema, A., and Papatla, P., "Relative Importance of Online Versus Offline Information for Internet Purchases: Product Category and Internet Experience Effects", Journal of Business Research, 63, 2010, pp. 979-985.

[50] Lin, J., Lu, Y., Wang, B., and Wei, K.K., "The Role of Inter-Channel Trust Transfer in Esablishing Mobile Commerce Trust", Electronic Commerce Research and Applications, 10(6), 2011, pp. 615-625.

[51] Balasubramanian, S., Raghunathan, R., and Mahajan, V., "Consumers in a Multichannel Environment: Product Utility, Process Utility, and Channel Choice", Journal of Interactive Marketing, 19(2), 2005, pp. 12-30.

[52] Coelho, P.S., and Jörg, H., "Creating Customer Loyalty through Service Customization", European Journal of Marketing, 46(3/4), 2012, pp. 331-356.

[53] Blázquez, M., "Fashion Shopping in Multichannel Retail: The Role of Technology in Enhancing the Customer Experience", International Journal of Electronic Commerce, 18(4), 2014, pp. 97-116.

[54] Barnes, L., and Lea-Greenwood, G., "Fast Fashioing the Supply Chain: Shaping the Research Agenda", Journal of Fashion Marketing and Management, 10(3), 2006, pp. 259-271.

[55] Kim, Y.-K., Park, S.-H., and Pookulangara, S., "Effects of Multi-Channel Consumers' Perceived Retail Attributes on Purchase Intentions of Clothing Products", Journal of Marketing Channels, 12(4), 2005, pp. 23-43. 